\title{
LIETUVOS SVEIKATOS MOKSLŲ UNIVERSITETO LIGONINĖS KAUNO KLINIKŲ AKUŠERIJOS IR GINEKOLOGIJOS SKYRIUJE 2015 M. ATLIKTŲ EPIZIOTOMIJŲ PAGRĮSTUMAS
}

\author{
Aušra Marija Obelenytė, Vytautas Abraitis \\ Lietuvos sveikatos mokslu universiteto Medicinos akademija
}

Raktažodžiai: epiziotomija, naujagimio hipoksija, tarpvietès plyšimas.

\section{Santrauka}

Šio darbo tikslas nustatyti epiziotomiju atlikimo pagrįstumą LSMUL KK Akušerijos ir ginekologijos skyriuje 2015 metais. Atlikta retrospektyvinè gimdyvių, kurioms buvo atlikta mediolateralinè epiziotomija bei naujagimių duomenų analizè. Statistinè duomenų analizė atlikta panaudojant „SPSS 24.0“ versijos statistini paketą. Darbe gauti rezultatai: dieninio/vakarinio intervalo metu priimta 52,23 proc. gimdymų, naktinio/rytinio intervalo metu $-47,77$ proc. Daugausia gimdymų priimta 17 ir 22 valandomis - po 6,2 proc., mažiausiai -8 valandą 2,2 proc. $(\mathrm{p}>0,05)$. Daugiausia epiziotomiju - 12,4 proc. atliko gydytojas nr. 6 ir akušerè nr. 13 - 6,6proc. $(\mathrm{p}<0,05)$. Dešimtadaliui naujagimių buvo nustatyta hipoksija ir acidoze kraujyje gimimo metu. 13,75 proc. $(n=103)$ stebejimo atvejų epiziotomija atlikta numatant, kad gims stambus vaisius $(\geq 4000 \mathrm{~g}), 2,7$ proc. $(\mathrm{n}=20)$ - remiantis numanoma užpakaline vaisiaus pakaušio pozicija. Epiziotomija atlikta po epidurinés nejautros - 39 proc. $(\mathrm{n}=289)$, kai gimdymas buvo užbaigtas vakuumo ekstraktoriumi $-2,7$ proc. $(\mathrm{n}=20)(\mathrm{p}<0,05)$. Atlikus duomenų analizę, paaiškèjo, jog III-IV laipsnio tarpvietės plyšimas įvyko tik 4 stebejjimo atvejams, t.y. 0,5 proc. visos tyrimo imties. Gautos išvados. Tik dešimtadaliui stebejimo atvejų epiziotomija buvo atlikta esant nestabilios vaisiaus būklès indikacijai. Epiziotomijų dažnis priklauso tiek nuo paros laiko, tiek nuo žmogiškojo faktoriaus. 99,5 proc. gimdyvių, kurioms buvo atlikta epiziotomija, gimdymo metu nepatyrè III-IV laipsnio tarpvietès plyšimo, todèl, remiantis literatūros šaltiniais, galima teigti, kad LSMUL KK Akušerijos ir ginekologijos skyriuje tar- pvietės apsauga yra geresnè nei kitose Europos šalyse.

Ivadas

Gimdyvès pasitikèjimas gydytoju yra vienas iš svarbiausių faktorių, užtikrinančių sèkmingą gimdymo eigą. Vienas labiausiai bauginančių besilaukiančias moteris faktorių yra neatitinkantis jų lūkesčių gimdymo stacionare dirbančiu gydytojų ir akušerių elgesys, paskatinantis moteris ieškoti alternatyvos. Kaip teigia D. Brogienè, kiekvienas praktikuojantis gydytojas akušeris-ginekologas pritartų, jog moteriai saugiausia gimdyti gimdymo stacionare, tačiau jos teigia, jog jaučiasi saugiau gimdydamos namuose, nes tikisi mažiau intervencijų, tokių kaip skatinimo, epiziotomijų, instrumentinių gimdymo užbaigimų [1]. İprastai šiose diskusijose moterys akcentuoja ne fizini, bet emocini ir psichologinį saugumą. $2006 \mathrm{~m}$. Ženevoje 19 tarptautinių organizacijų paskelbė tarptautinę „Motinai ir naujagimiui palankaus gimdymo" iniciatyvą [2]. Šioje iniciatyvoje suformuluota 10 žingsnių,remiantis „Motinai palankaus gimdymo iniciatyvos" koalicijos CIMS (The Coalition for Improving Maternity services) ekspertu darbo grupès atlikta sistemine mokslinių tyrimų (nuo 1990 iki 2006 m.) apžvalga. Viename iš šių žingsnių teigiama, jog „Motinai palanki ligoninë“sumažina tokias intervencijas, kaip gimdymo stimuliacija 10 proc. ar mažiau, bei epiziotomijų 20 proc. ar mažiau, siekiant jas sumažinti iki 5 proc.[3]. Epiziotomija, kaip medicinine intervencija iškelia probleminị klausimą, ar epiziotomijos atlikimas, gresiant tarpvietės plyšimui, yra pagrịstas, kaip neišvengiama būtinybe siekiant pagerinti gimdymo eigą ir išvengiant pogimdinių komplikacijų, ar tai mokslu nepagristos intervencijos taikymas, sukeliantis daug nepageidaujamų pasekmių, tarp jų ir gimdžiusių moterų nepasitenkinimą bei nepasitikejjimą medikais.

Darbo tikslas - nustatyti epiziotomijų atlikimo pagrịstumą LSMUL KK Akušerijos ir ginekologijos skyriuje 2015 metais. 


\section{Tyrimo medžiaga ir metodai}

Epiziotomijos atlikimas vaginaliniame gimdyme pirmą kartą buvo rekomenduotas $1920 \mathrm{~m}$. kaip būdas, skirtas apsaugoti moters tarpvietę nuo plèštinès žaizdos, o kūdikị nuo traumos. Jis buvo gana greitai ịsisavintas, kaip standartinè praktika ir nuo tada yra gana plačiai naudojamas[4]. Kai kurių šalių gydymo ịstaigose epiziotomijos atliekamos rutiniškai [5].Tačiau skirtingose šalyse epiziotomijos taikymas yra nevienodas. Daugiausia epiziotomijų atliekama Rytu Europoje[6]. Pastaruoju metu rutiniškai atliekamų epiziotomijų dažnis sumažejo visose šalyse. Medicininių intervencijų, tarp jų ir epiziotomijų, panaudojimas yra vienas iš pagrindinių veiksnių, apibūdinančių gimdymo priežiūros kokybę. Ji vertinama blogiau, jei medicininès intervencijos taikomos nepagrịstai. Pasak E. Švedo, epiziotomija yra viena iš dažniausių akušerinių procedūrų, kurių naudojimas normalų gimdymą paverčia didelès rizikos gimdy$\mathrm{mu}$ [7].Mokslininkai teigia, jog yra sąsajos tarp atliekamos epiozotomijos tipo ir analinio sfinkterio traumų rizikos[8]. Epiziotomija paprastai atliekama gimdymo metu tikint, jog ji apsaugo nuo tarpvietès plyšimo, dubens dugno raumenų atsipalaidavimo ir šlapimo nelaikymo, taip pat, kad ji apsaugos naujagimi nuo gimdymo traumos ir asfiksijos [9].

Rutiniška ir indikuotina epiziotomija. Per pastaruosius kelis dešimtmečius, kaip teigia J.R.Lappen ir D.R.Gosset[4], buvo surinkti įrodymai, paneigiantys rutiniškai atliekamos epiziotomijos naudą priešpastatant jai ateityje galinčias pasitaikyti sunkias moters dubens dugno disfunkcijas. Tačiau pastebèta, jog nèra vieningos mokslininkų nuomonès apie rutiniškai atliekamos ir indikuotinos epiziotomijos naudą. C. Cam, M. Asoglu ir kt. retrospektyvioje duomenų analizèje pateikta išvada, jog mediolateralinè epiziotomija padeda išvengti priekinès makšties sienelès pažeidimų. Siekant padaryti patikimas galutines išvadas reikia atlikti prospektyvius randomizuotus tyrimus [10]. V. Handa, J. Blomquist ir kt. DDD kohortinès studijos planinejje analizejje pateikè išvadas, jog replių taikymas gimdymo metu ir tarpvietès plèštinès žaizdos, bet ne epiziotomija, buvo susiję su DDD 5-10 metu laikotarpiu po pirmojo gimdymo [11].

G. Carroli, L. Mignini teigia, jog epiziotomijos, atliktos pagal indikacijas, nauda žymiai didesnè. Sunkių tarpvietès traumų, siuvimo ir gijimo komplikacijų per septynias dienas sumažejo nuo 12 proc. iki 31 proc. [5]. K. Hartmann, M. Viswanathan ir kt. nustatè, jog epiziotomija nèra naudinga sveikatai, tarp rutiniškai taikomos ir indikuotos epiziotomijos esminių skirtumų šiuo aspektu taip pat nėra [12]. Vis dèlto dauguma Vakarų šalių autorių rekomenduoja atsisakyti rutiniškos epiziotomijos ir atlikti ją esant rimtoms indikacijoms [8], ypač esant nestabiliai vaisiaus būklei.
Tyrimo metodai. Tyrimo duomenims surinkti buvo pasirinkta retrospektyvinė 2015 metu Akušerijos ir ginekologijos skyriuje gimdžiusių moterų, kurioms buvo atlikta mediolateralinè epiziotomija, duomenų analizè. Klinikiniai duomenys surinkti iš ligos istorijų. Tyrime analizuojama vienuolika kintamujų: gimdyvių amžius, gimdymo laikas, gimdymo komplikacija (III-IV laipsnio tarpvietès plyšimas), naujagimio lytis, ūgis, svoris, Apgar balas po $1 \mathrm{~min}$ ir po $5 \mathrm{~min}$, virkštelès arterijos kraujo $\mathrm{pH}$, intervenciją atlikęs gydytojas ir akušerè.

Tyrimo duomenų apdorojimo metodai. Statistinè duomenų analizè atlikta „SPSS 24.0“ versijos statistikos paketu.Duomenu matrica apdorota „Microsoft Office Excel 13.0"versijos kompiuterine programa. Analizès metu buvo vertinamos įvairios duomenų padèties charakteristikos. Kiekybinių kintamujų (gimdyvių amžius, gimdymo laikas, naujagimio ūgis, svoris, virkštelès arterijos ph) - aritmetinis vidurkis, standartinis nuokrypis, dažnis, maksimali bei minimali reikšmès. Nominalių kintamujjų (naujagimio lytis, intervenciją atlikęs gydytojas ir akušerè, III-IV laipsnio tarpvietès plyšimas) - dažnis. Ranginių kintamųų (Apgar balas po $1 \mathrm{~min}$ ir po $5 \mathrm{~min}$ ) - aritmetinis vidurkis, standartinis nuokrypis, dažnis, maksimali bei minimali reikšmès. Vertinant kintamujų tarpusavio ryšį atsižvelgiama ị statistnị reikšmingumą. Ryšys laikomas statistiškai reikšmingu, kai $\mathrm{p}<0,05$. Statistinio reikšmingumo ịvertis parodo, kokia yra tikimybe, kad gautas rezultatas nèra atsitiktinis ir rodo tiriamą efektą.

Kiekybinio tyrimo kokybiškumą rodo keletas kriterijų: reprezentatyvumas, validumas ir patikimumas. Atliktas tyrimas tenkina visus šiuos kriterijus. Kadangi tyrimo imtis (gimdyvių - 741, naujagimių - 749) yra lygi tyrimo populiacijai (tyrimo metu nebuvo naudojama jokia atranka), ši tyrimą galima laikyti reprezentatyvų bei juo remiantis daryti plačias generalizacijas ir rekomendacijas. Tyrimo rezultatai yra validūs ir patikimi - ištirta tai, kas norèta ištirti bei pakartojus ši tyrimą būtų gaunami tie patys rezultatai.

Tiriamujų atranka. Tiriamujų grupé sudaryta atrankos metodu, remiantis tik vienu kriterijumi, kad gimdyvei tiriamu laikotarpiu LSMUL KK Akušerijos ir ginekologijos skyriuje buvo atlikta mediolateralinè epiziotomija.

Tiriamojo kontingento charakteristika. Naujagimiai. Analizuoti 749 naujagimių duomenys. Vyriškosios lyties naujagimių buvo 55,06 proc. $(\mathrm{n}=408)$, moteriškosios lyties $-44,94$ proc. $(\mathrm{n}=341)$. Naujagimių svorio vidurkis

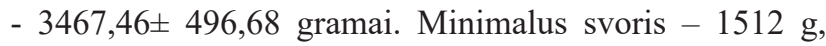
maksimalus svoris - 5350g. Naujagimių, svèrusių $\geq 4000 \mathrm{~g}$, buvo 13,75 proc. $(\mathrm{n}=103)$.Naujagimiai, sveriantys daugiau $\geq 4000$ g, yra kaip rizikos veiksnys savaiminiam giliam tarpvietès plyšimui [13]. Moteriškosios lyties naujagimių 
svorio vidurkis $-3392,48 \pm 498,92 \mathrm{~g}$, vyriškosios $-3530,51$ $\pm 487,09$ g. Naujagimių ūgio vidurkis $-54,54 \pm 2,41$ centimetrai. Maksimalus ūgis $-58 \mathrm{~cm}$, minimalus $-40 \mathrm{~cm}$.

Gimdyvès. Analizuoti 741 gimdyvès duomenys. Tyrime dalyvavusių gimdyvių amžiaus vidurkis gimdymo metu buvo 29,65 5,13 metai (jauniausiai 16 metų, vyriausiai 45 metai).

\section{Tyrimo rezultatai ir jų aptarimas}

Epiziotomijų atlikimas pagal paros laiką. Gimdymo laikas buvo susikirstytas $\mathfrak{i}$ du intervalus: dienini/vakarini (8:00-19:59) ir naktinị/rytinị(20:00-07:59), remiantis Webb D. A. ir kt. tyrimu [14]. Dieninio/vakarinio intervalo metu atlikta 52,23 proc. $(\mathrm{n}=387)$ epiziotomijų, iš visų stebejjimo atveju, naktinio/rytinio intervalo metu $-47,77$ proc. $(n=354) . P>0,05$. Atlikus duomenų analizę nustatyta, jog daugausiai epiziotomijų atlikta 17 ir 22 valandomis - po 6,2 proc., mažiausiai -8 valandą - 2,2 proc.

Epiziotomijų atlikimas pagal medicinos personalą. Iš viso per tiriamaji laikotarpi atlikta 741 epiziotomija. Atlikus duomenų analizę, nustatyta, jog gimdymus prièmè ir epiziotomijas atliko 28 gydytojai ir 26 akušerès. Siekiant laikytis tyrimo etikos reikalavimų, gydytojų ir akušerių pavardès buvo užkoduotos, žymint jas skaičiais nuo 1 iki 28 gydytojams ir nuo 1 iki 26 akušerèms. Epiziotomijų skaičiaus vidurkis, tenkantis vienam gydytojui: $\bar{X}=26,46$. Iš 28 gydytojų 13 atliko epiziotomijų daugiau už vidurki $\overline{\mathrm{X}}$ $\geq 26,46$ (nuo 27 iki 92). Išreiškus procentais nuo bendro atliktų epiziotomijų skaičiaus, šių gydytojų bendras atliktų epiziotomijų procentinis intervalas nuo 12,4 proc. iki 3,6 proc. Mažiau už vidurki $\overline{\mathrm{X}} \leq 26,46$ epiziotomijų atliko 15 gydytojų, kurių atliktų epiziotomijų procentas gerokai mažesnis nuo 2,8 proc. iki 0,1 proc. nuo bendro epiziotomiju skaičiaus.

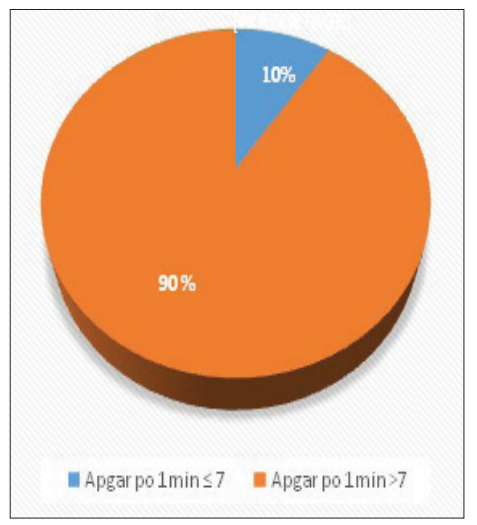

1 diagrama. Naujagimių Apgar balas po 1 minutès
Epiziotomijų skaičiaus vidurkis, tenkantis vienai akušerei: $\bar{X}=28,5$. Iš 26 akušerių 14 atliko epiziotomijų daugiau už vidurkị $\overline{\mathrm{X}} \geq 28,5$ (nuo 82 iki 31 ). Išreiškus procentais nuo bendro atliktų epiziotomijų skaičiaus, šių akušerių bendras atliktų epiziotomijų procentinis intervalas svyruoja nuo 11,1 proc. iki 4,3 proc. Mažiau už vidurki $\overline{\mathrm{X}} \leq 26,46$ epiziotomijų atliko 12 akušerių (nuo 28 iki 1), kurių bendras atliktų epiziotomijų procentinis intervalas yra nuo 3,8 iki 0,1 proc. nuo bendro epiziotomijų skaičiaus. Pagal ịrašus ligos istorijoje negalima spręsti, jog daugiausia epiziotomijų atlikęs gydytojas ir akušerè dirba kartu.

Epiziotomijų atlikimas pagal indikaciją; nestabili vaisiaus būklè. Nestabili vaisiaus būklè patvirtinama tik retrospektyviai vertinant Apgar balą po 1 minutès ir po 5 min po gimimo bei tuoj po gimimo atlikto virkštelès arterijos kraujo $\mathrm{pH}$ tyrimo. Atlikus duomenų analizę paaiškejjo, jog iš 749 naujagimių, kurių motinoms buvo atlikta epiziotomija, Apgar balu po 1min vidurkis $-8,75 \pm 1,13$. Minimalus balas - 0, maksimalus - 10. Apgar balų po $5 \mathrm{~min}$

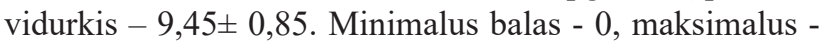
10. Daugiau nei pusès naujagimių (55,3 proc.) Apgar balas po 1 min buvo lygus 9. Net 60,1 proc. naujagimių Apgar balas po $5 \mathrm{~min}$ buvo lygus 10 . Duomenų analizè patvirtino, jog mažiau nei dešimtadalis naujagimių patyre hipoksiją gimimo metu (Apgar balas $\leq 7$ ). (1 ir 2 diagramos).

Tuoj po gimimo 35,38 proc. $(\mathrm{n}=265)$ naujagimių buvo atliktas virkštelès arterijos kraujo $\mathrm{pH}$ tyrimas. Išanalizavus duomenis nustatytas $\mathrm{pH}$ vidurkis $-7,23 \pm 0,103$. Minimalus pH lygis - 6,89, maksimalus - 7,49. Daugiau nei dešimtadaliui naujagimių $-11,88$ proc. $(n=89)$ buvo nustatyta acidozè kraujyje, virkštelès arterijos kraujo $\mathrm{pH}<7,2$. Remiantis A. Kudrevičienès ir kt. [16] analizès duomenimis, kai virkštelès kraujo $\mathrm{pH}<7,2$ - tai traktuojama kaip acidozè, patvirtinanti, jog yra naujagimio hipoksija.

Apibendrinant epiziotomijos pagristumą pagal indikaciją - nestabili vaisiaus būklè - galima teigti, jog stebi-

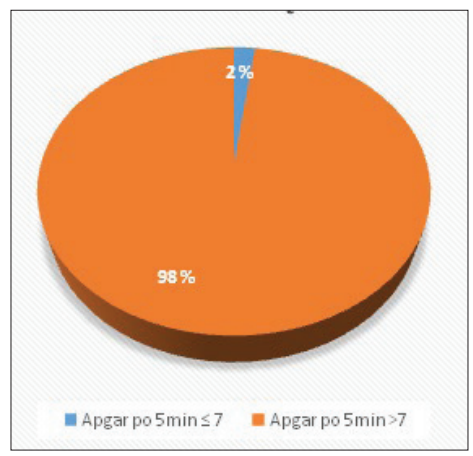

2 diagrama. Naujagimių Apgar balas po 5 minučių 
miems atvejams epiziotomijos buvo atliekamos remiantis šia indikacija. Tačiau nestabilią vaisiaus būklę patvirtinanti hipoksija po gimdymo nustatyta tik dešimtadaliui naujagimių. Todèl šiuo požiūriu dauguma epiziotomijų galima vertinti kaip nepagristai atliktas.

Epiziotomijų atlikimas pagal indikaciją galimas III - IV laipsnio tarpvietès plyšimas. Tarpvietès plyšimas galimas esant predisponuojantiems faktoriams, vieni faktoriai yra prognozuojami (stambus vaisius $(\geq 4000 \mathrm{~g}$ ), vaisiaus užpakalinė pakaušio pozicija (visus dorsoposterior), kiti žinomi (epidurinè nejautra, instrumentinis gimdymo užbaigimas). Išanalizavus duomenis paaiškèjo, kad 13,75 proc. $(\mathrm{n}=103)$ stebejimo atvejų epiziotomija buvo atlikta remiantis numanomu vaisiaus svoriu $(\geq 4000 \mathrm{~g}), 2,7$ proc. $(\mathrm{n}=20)$ - remiantis numanoma užpakaline vaisiaus pakaušio pozicija. Esant žinomiems rizikos veiksniams epiziotomija atlikta dažniau, po epidurinès nejautros - 39 proc. $(\mathrm{n}=289)$, kai gimdymas buvo užbaigtas vakuumo ekstraktoriumi $-2,7$ proc. $(\mathrm{n}=20)$. $\mathrm{P}<0,05$.Atlikus duomenu analizę, paaiškejjo jog III-IV laipsnio tarpvietès plyšimas įvyko tik 4 stebejimo atvejams, t.y. 0,5 proc. visos tyrimo imties. Remiantis Blondel B. ir kt. [16] duomenimis, III - IV laipsnio tarpvietės plyšimo dažnis Europos šalyse (Danijoje 4,8 proc., Estijoje 0,9 proc., Suomijoje 1,1 proc., Vokietijoje 1,8 proc., Islandijoje 4,9 proc., Švedijoje 3,5 proc., Olandijoje 2,7 proc., Jungtineje Karalysteje 3,2 proc.) didesnis nei LSMUL KK Akušerijos ir ginekologijos skyriuje. Todèl galima teigti, kad tarpvietès apsauga yra gera ir šiuo požiūriu atliktos epiziotomijos sąlyginai apsaugojo nuo galimo spontaninio tarpvietès plyšimo.

Atlikus tyrimą, gautuose rezultatuose atsipindi, kad didžioji dalis epiziotomijų buvo atlikta nesant indikacijų, nepaisant to, kad gimdymą prižiūrintys asmenys pasirenka atlikti epiziotomiją atsižvelgdami ị klinikinę situaciją. Iš 749 naujagimių, tik dešimtadaliui po gimimo buvo patvirtinta hipoksija ir acidozè kraujyje. Siekiant sumažinti epiziotomijų skaičių, pirmiausia reikètų idiegti informuoto sutikimo formas. Šiuo metu iš visų akušerinių intervencijų tik cezario pjūvio operacija turi informuoto sutikimo formą. Taip pat apie epiziotomijos atlikimo galimybę reiktų aptarti su gimdyve,geriausiai iki antrojo gimdymo laikotarpio pradžios. Tuomet atsižvelgiant i gimdyvès nuomonę, patvirtintą parašu sutikimo formoje, gimdymą prižiūrintys asmenys negalètu atlikti nepagrịstos intervencijos. Kitas būdas mažinti epiziotomijų dažni - pažymèti epiziotomijos indikaciją gimdymo istorijoje, šiuo metu pažymima tik cezario pjūvio operacijos indikacija. Toks sprendimas didintų gimdymą prižiūrinčiu asmenų atsakomybę, todèl epiziotomijos būtų atliekamos tik esant patvirtintoms indikacijoms (nestabili vaisiaus būklè, galimas spontaninis gilus tarpvietės plyšimas). Indikacijos pažymèjimas gimdymo istorijoje leistų nustatyti, kuris tarpvietės plyšimą predisponuojantis faktorius (stambus vaisius $(\geq 4000 \mathrm{~g}$ ), epidurinè nejautra,vaisiaus užpakalinė pakaušio pozicija (visus dorsoposterior), instrumentinis gimdymo užbaigimas) yra prognostiškai blogiausias. Todèl ateityje būtų galima tiksliau prognozuoti gimdymo eigą ir baigti.

\section{Išvados}

1. Tiriamajame darbe nagrinètos kelios epiziotomijos indikacijos - nestabili vaisiaus būklè bei galimas spontaninis gilus tarpvietès plyšimas. Tik dešimtadaliui stebejimo atvejų epiziotomija buvo atlikta esant nestabilios vaisiaus būklès indikacijai.Tačiau nestabilią vaisiaus būklę patvirtinanti hipoksija retrospektyviai po gimdymo nustatyta tik dešimtadaliui naujagimių. Todèl šiuo požiūriu dauguma epiziotomijų galima vertinti kaip nepagristai atliktas.

2. 99,5 proc. gimdyvių, kurioms buvo atlikta epiziotomija, gimdymo metu nepatyre III-IV laipsnio tarpvietės plyšimo, todèl remiantis literatūros šaltiniais, galima teigti, kad LSMUL KK Akušerijos ir ginekologijos skyriuje tarpvietės apsauga yra geresnè nei kitose Europos šalyse.

3. Kadangi nèra išskirta aiškių epiziotomijos atlikimo indikacijų, sprendimą atlikti intervenciją priima prižiūrintis gimdymą asmuo, remdamasis klinikine situacija. Tyrimo metu nustatyta, kad epiziotomijų dažnis taip pat priklauso ir nuo žmogiškojo faktoriaus, vieni gydytojai ir akušerès epiziotomiją atlieka statistiškai patikimai dažniau nei kiti.

4. Paros laikas taip pat turejo įtakos atlikti epiziotomijas, nes remiantis atliktu tyrimu (dieninio/vakarinio intervalo metu atlikta 52,23 proc. epiziotomijų, iš visų stebèjimo atvejų, naktinio/rytinio intervalo metu $-47,77$ proc.) ir, literatūros duomenimis, epiziotomijos dažniau atliekamos pirmoje dienos pusejje.

\section{Literatūra}

1. Brogienė D. Planuotas gimdymas namuose - naujas iššūkis motinystės priežiūrai Lietuvoje. Lietuvos akušerija ir ginekologija, 2012; 25(2): 106-108.

2. Kulikauskaitė B. "Motinai palankaus gimdymo" iniciatyva. Lietuvos akušerija ir ginekologija, 2008; 25 (4):335.

3. Lothian JA. Coalition for improving maternity services. Evidence basis for the ten steps of motherfriendly care: a systematic review. The Journal of Perinatal Education 2007; 16(1)1-96. http://dx.doi.org/10.1624/105812407X173119

4. Lappen JR, Gossett DR. Changes in episiotomy practice: evidence-based medicine in action. Expert Review of Obstetrics \& Gynecology 2010; 5(3): 301-309.

http://dx.doi.org/10.1586/eog.10.21

5. Carroli G, Mignini L. Episiotomy for vaginal birth. Cochrane 
Database of Systematic Reviews 2009, Issue 1. Art. No.: CD000081.

http://dx.doi.org/10.1002/14651858.CD000081.pub2

6. Tarpvietės plyšimai. Epiziotomijos. Metodika. 2014. Prieiga internete https://sam.lrv.lt/uploads/sam/documents/files/ Veiklos_sritys/Programos_ir_projektai/Sveicarijos_parama/ Akuserines\%20metodikos/Tarpvietes\%20plysimai_\%20Epiziotomijos.pdf. Žiūrèta 20160501

7. Švedas E. İrodymais pagrịsta normalaus gimdymo priežiūra. Lietuvos akušerija ir ginekologija, 2008; 12(4): 344-347.

8. Stedenfeldt M, Pirhonen J, Blix E, Wilsgaard T, Vonen B, Øian P. Episiotomy characteristics and risks for obstetric anal sphincter injuries: a case-control study. BJOG: An International Journal of Obstetrics and Gynaecology 2012; 119:724-730. http://dx.doi.org/10.1111/j.1471-0528.2012.03293.x

9. Walling A. Effect of episiotomy on pelvic floor weaknes. American FamilyPhysician 2005 Feb 1; 71(3):588.

10. Cam C, Asoglu MR, Selcuk S, Aran T, Tug N, Karateke A. Does mediolateral episiotomy decrease central defects of the anterior vaginal wall? Archives of Gynecology and Obstetrics 2012; 285(2):411-415. http://dx.doi.org/10.1007/s00404-011-1965-z

11. Handa VL, Blomquist JL, McDermott K, Friedman S, Mu-oz A. Pelvic floor disorders after childbirth: effect of episiotomy, perineal laceration, and operative birth. Obstetrics and Gynecology 2012; 119(2): 233-239.

http://dx.doi.org/10.1097/AOG.0b013e318240df4f

12. Hartmann K, Viswanathan M, Palmieri R, Gartlehner G, Thorp J, Lohr K. Outcomes of routine episiotomy a systematic review. JAMA: The Journal of the American Medical Association 2005; 293(17):2141-2148.

http://dx.doi.org/10.1001/jama.293.17.2141

13. Rouse DJ, Owen J, Goldenberg RL, Cliver SP. The effectiveness and costs of elective ceasarean delivery for fetal macrosomia diagnosed by ultrasound. JAMA: The Journal of the American Medical Association 1996; 276(18):1480-1486. http://dx.doi.org/10.1001/jama.1996.03540180036030

14. Webb DA, Culhane J. Time of day variation in rates of obstetric intervention to assist in vaginal delivery. Journal of Epidemiology and Community Health 2002; 56:577-578. http://dx.doi.org/10.1136/jech.56.8.577

15. Kudrevičienė A., Basevičius A., Lukoševičius S., Grigonienė J., Marmienė V. ir kt. Virkštelès arterijos kraujo pH, BE, bikarbonatų ir laktatų reikšmè išnešioto naujagimio gaivinimo poreikiui, galvos smegenų kraujotakos pokyčiams ir hipoksinei išeminei encefalopatijai. Lietuvos akušerija ir ginekologija, 2011; 14 (3):180-189.
16. Blondel B, Alexander S, Bjarnadóttir RI, Gissler M, LanghoffRoos J, Novak-Antolič Ž. et al. Variations in rates of severe perineal tears and episiotomies in 20 European countries: a study based on routine national data in Euro-Peristat Project. Acta Obstetricia and Gynecologica Scandinavica 2016.

http://dx.doi.org/10.1111/aogs. 12894

\section{EPISIOTOMY VALIDITY PERFORMED IN HOSPITAL OF LITHUANIAN UNIVERSITY OF HEALTH SCIENCES KAUNO CLINICS IN DEPARTMENT OF OBSTETRICS AND GYNECOLOGY IN 2015}

A. M. Obelenytė, V. Abraitis

Key words: episiotomy, perinatal hypoxia, perineal tear. Summary

Aim of the study - the evaluation of episiotomy validity performed in Department of Obstetrics and Gyneclogy in 2015. Methods. Performed a retrospective study involving 741 cases of mediolateral episiotomy. Clinical data of mothers and newborns was analyzed. Statistical analysis was performed using SPSS 24.0 software package.

Results. At daytime/evening hours was received 52,23\% labours, night-time/morning hours $-47,77 \%$. Most births received at 5 p.m.(6,2\%) and 10 p.m.(6,2\%), least - at 8 a.m (2,2\%). A small number of physicians and midwife performed most of episiotomy. More than $10 \%$ of newborn at birth was found with hypoxia and acidosis in blood. $13,75 \%(\mathrm{n}=103)$ of episiotomies was done on the basis of expection of heavy fetus ( $\geq 4000 \mathrm{~g}), 2,7 \%$ ( $n=20)$ - on the basis of occipital posterior fetal position. $39 \%(n=289)$ of episiotomies was done after the epidural anesthesia and 2,7\% after giving-birth using vacuum extractor $(p<0,05)$. Analysis of the data showed that the III-IV degree perineal tears occurred in only 4 cases $-0,5 \%$ of all subjects.

Conclusions. Only in one tenth of the cases episiotomy was performed due to indication of unstable fetus condition. Episiotomy rate depends both on the time of day and the human factor. 99,5\% of women didn't suffer from the III-IV degree perineal tears, so we can state that the protection of perineal area is better in department of Gynaecology and Obstectrics at LUHS Clinics comparing with other sources of literature and European countries.

Correspondence to: mobelenyte@gmail.com

Gauta 2016-05-31 